\title{
Growth rates of planktonic and newly settled American lobsters Homarus americanus
}

\author{
Mary-Jane James-Pirri* , J. Stanley Cobb \\ Department of Biological Sciences, University of Rhode Island, Kingston, Rhode Island 02881, USA
}

\begin{abstract}
Growth rates, as estimated by the RNA:DNA ratio, were determined for planktonic postlarvae and for recaptured and wild newly settled benthic stages (fifth and sixth instars) of the American lobster Homarus americanus. The mean growth rate of planktonic postlarvae in 1994 was $0.522 \pm$ $0.247 \mathrm{mg}$ protein $\mathrm{d}^{-1}$. This was significantly higher than planktonic growth rates observed in 1991 $\left(0.449 \pm 0.121 \mathrm{mg}\right.$ protein $\left.\mathrm{d}^{-1}\right)$ but not in $1992\left(0.460 \pm 0.144 \mathrm{mg}\right.$ protein $\left.\mathrm{d}^{-1}\right)$. The percentage of poorly nourished planktonic postlarvae, those with growth rates $<0.220 \mathrm{mg}$ protein $\mathrm{d}^{-1}$, ranged from 3 to $13 \%$ in 1991, 1992 and 1994 and was similar to that observed in previous years (1988 to 1990). Newly settled lobsters had significantly lower mean growth rates $\left(0.223 \pm 0.180 \mathrm{mg}\right.$ protein $\left.\mathrm{d}^{-1}\right)$ than planktonic postlarvae. Recaptured lobsters originating from wild stock had significantly higher growth rates than those originating from laboratory stock $\left(0.281 \pm 0.176\right.$ vs $0.085 \pm 0.078 \mathrm{mg}$ protein $\mathrm{d}^{-1}$, respectively). Laboratory rearing effects (lowered growth rates) appeared to persist even after 1 wk in the field. The differences in the growth rates between planktonic and benthic phase lobsters may be evidence of a tradeoff between slow growth due to decreased food ingestion and potential increased vulnerability to predation when actively foraging.
\end{abstract}

KEY WORDS: RNA:DNA ratios Growth rates Homarus americanus - Settlement

\section{INTRODUCTION}

Understanding the mechanisms that influence cohort size is instrumental for effective management of economically important species. Determination of cohort size may occur at one or more 'critical' phases in the life history of an organism. For the American lobster Homarus americanus, the period spanning the fourth instar or postlarva to fifth instar has been identified as a 'critical' phase (Langton et al. 1996). The postlarva is the transitional stage between the planktonic larval habitat and the benthic adult habitat. In coastal Rhode Island (USA) waters, postlarvae first appear in the plankton in mid June when surface water temperature reaches $16^{\circ} \mathrm{C}$ and are present through late July to early August (James-Pirri 1996, J. S. Cobb unpubl.

- Present address: Rhode Island Public Health Partnership in Infectious Disease Control, Office of Mosquito Abatement Coordination, Stedman Government Center, 4808 Tower Hill Road, Wakefield, Rhode Island 02879, USA

E-mail:mvt101@uriacc.uri.edu data). Shortly after settlement, the postlarva molts to the fifth instar and becomes a fully benthic organism (Charmantier et al. 1991). This phase of the lobster's life history (carapace length 4 to $14 \mathrm{~mm}$ ) has been characterized as the shelter-restricted juvenile stage (Lawton \& Lavalli 1995). Shelter-restricted juveniles are most abundant in cobble habitats in shallow (2 to $7 \mathrm{~m}$ ) waters (Wahle \& Steneck 1991). During this period, lasting probably several months, it has been suggested that the juvenile lobster primarily remains within the protection of its burrow, with limited movements outside of the shelter (Lawton \& Lavalli 1995). It has been hypothesized that small juvenile lobsters trade off maximizing foraging for predator avoidance, with the smallest juveniles (newly settled) incurring the greatest risk (Wahle 1992, Wahle \& Steneck 1992). However, growth rates of newly settled lobsters have not yet been evaluated.

Growth rates for the postlarval instar have been estimated by the ratio of total RNA to total DNA and water temperature. While total DNA remains constant per 
cell, total RNA is variable. Generally, higher concentrations of RNA are associated with greater protein synthesis and growth (Bulow 1987). This method is a sensitive indicator of recent ( 2 to 3 d) feeding history of the postlarval instar and thus indirectly of its nutritional condition (Juinio et al. 1992, Juinio \& Cobb 1994). Differences in growth rates between planktonic and benthic phase lobsters may be evidence of a tradeoff between slow growth due to decreased food ingestion and the potential increased vulnerability to predation when actively foraging. In this study we report the growth rates of field-caught planktonic postlarvae and newly settled early benthic lobsters as determined by nucleic acid analysis.

\section{METHODS}

Planktonic postlarvae. All postlarval lobsters were collected weekly from 2 sampling stations (Harbor of Refuge and Bell 4) less than $2 \mathrm{~km}$ apart in Block Island Sound near Point Judith, Rhode Island, from mid June

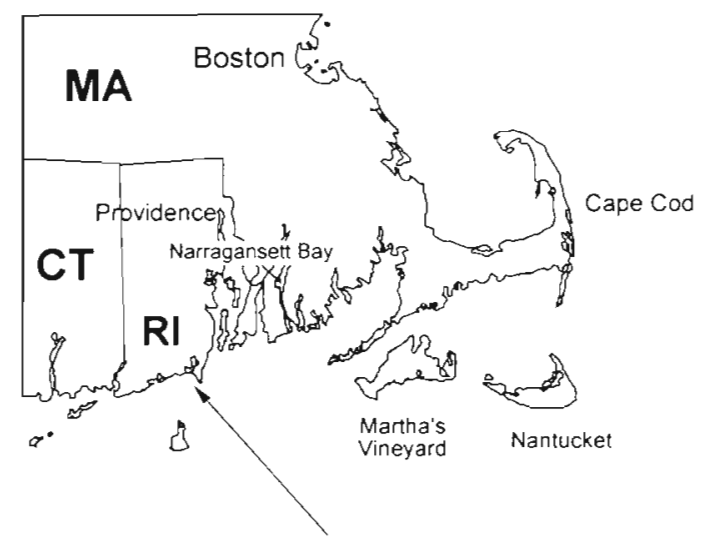

Point Judith Harbor of Refuge

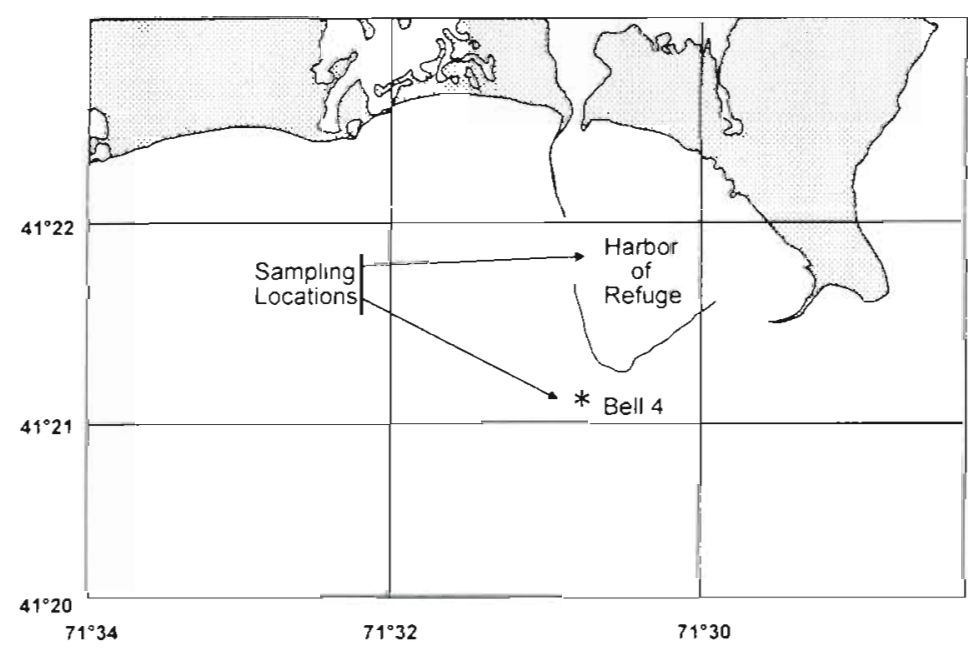

Fig. 1. Map of southern New England, USA, showing sampling locations until mid August in 1991, 1992 and 1994 (Fig. 1). Although sampling occurred in 1993, postlarvae were virtually absent from the waters off of Rhode Island during this year Planktonic postlarval lobsters were sampled using paired neuston nets (500 $\mu \mathrm{m}$ mesh, mouth opening $1.0 \times 0.5 \mathrm{~m}$ ) equipped with flow meters and towed from the sides of a small research vessel travelling at approximately 1.5 knots. Sea surface temperature was recorded at each sampling location. Postlarvae were removed from the plankton sample, placed in vials of sea water and held on ice until returning to the laboratory. In the laboratory the molt cycle stage of all postlarvae was determined according to Sasaki (1984). Postlarvae were placed in separate vials and stored at $-80^{\circ} \mathrm{C}$ for later nucleic acid analysis.

Early benthic phase lobsters. Early benthic phase lobsters were sampled weekly from July through September in 1994 in the Point Judith Harbor of Refuge, Rhode Island (Fig. 1). The Harbor of Refuge is a wellmixed body of water ranging in depth from 2 to $8 \mathrm{~m}$. Benthic samples were collected using SCUBA and a benthic air lift suction sampler. A $0.5 \mathrm{~m}^{2}$ quadrat was haphazardly thrown over suitable cobble substrate and all organisms within the quadrat sampled. Bottom water temperature was recorded for each sample. Benthic samples were sorted immediately and all lobsters were measured using vernier calipers. Lobsters less than $10 \mathrm{~mm}$ carapace length (CL) were returned to the laboratory, molt cycle stage was determined and the lobsters were stored individually at $-80^{\circ} \mathrm{C}$ for later nucleic acid analysis. Lobsters less than $10 \mathrm{~mm}$ have been identified as the current year class of new recruits (Cobb \& Wahle 1994). Early benthic phase lobsters recaptured from field tag and recapture experiments conducted in the Harbor of Refuge in 1993 and 1994 were also analyzed for total RNA and DNA. Details of the tag recapture study are reported in James-Pirri (1996). Briefly, in the tag-recapture experiments, laboratory reared fifth instars (in 1993) and wild postlarvae (in 1994) were tagged with binary coded micro-wire tags (Northwest Marine Technology, Inc, Shaw Island, WA, USA). After tagging, lobsters were held in the laboratory for 2 to $4 \mathrm{~d}$ before being transplanted into the field. While in the laboratory, tagged lobsters were held in individual containers in flow-through ambient seawater and fed adult frozen brine shrimp ad libitum.

In 1993 lobsters originating from laboratory stock (reared from egg to fifth instar) were transplanted to the field as fifth instars. In 1994, transplanted lobsters originated from wild stock; they had been caught as planktonic postlarvae and were transplanted 
into the field as postlarvae. Tagged lobsters were transplanted into cobble plots in approximately $5 \mathrm{~m}$ of water in the Harbor of Refuge using SCUBA (JamesPirri 1996). Plots were sampled approximately $1 \mathrm{wk}$ later with a benthic air lift suction sampler. Bottom water temperature was recorded for each sample. Samples were sorted immediately and all lobsters collected were returned to the laboratory where CL was measured and molt cycle stage was determined. Recaptured lobsters were individually identified by extracting the micro-wire tag and reading the binary code. They were then stored individually at $-80^{\circ} \mathrm{C}$ for later nucleic acid analysis. Growth rates are reported for the 1993 laboratory reared lobsters transplanted as fifth instars and recaptured as sixth instars, and for the 1994 wild caught postlarvae transplanted as postlarvae and recaptured as fifth instars. In both years, growth rates of transplanted lobsters are for those individuals that molted once while in the field prior to recapture.

Growth rates. Average growth rates of individual postlarvae, recaptured lobsters and wild early benthic phase lobsters (<10 mm CL) were determined by analyzing the ratio of total RNA to total DNA (Juinio et al. 1992, Juinio \& Cobb 1994). Nucleic acid analysis was determined for lobsters in intermolt condition (molt cycle stages $C$ and $D_{0}$ ), as these molt cycle stages are the best predictors of recent growth history (Juinio 1991, Juinio et al. 1992). Individuals were freeze dried and dry weight was determined using a Metler analytical balance. Total RNA and DNA were determined using a modification of the Schmidt-Thannhausser method for larval fish (Buckley 1979) adapted for postlarval lobsters (Juinio 1991, Juinio et al. 1992). Each lobster was homogenized in distilled water to reach a final concentration of $6 \mathrm{mg}$ dry $w \mathrm{t} \mathrm{ml}^{-1}$. Total RNA and DNA was determined for 2 replicates from each individual. Temperature-corrected growth rates (mg protein $\mathrm{d}^{-1}$ ) were estimated from the ratio of total RNA to DNA and water temperature (sea surface for planktonic postlarvae or bottom temperature for benthic lobsters) at the time of collection using the postlarval lobster growth model developed by Juinio (1991) and Juinio \& Cobb (1994): Growth rate $=-0.778+0.268 R+$ $0.01 T$, where $R$ is the RNA:DNA ratio and $T$ is water temperature $\left({ }^{\circ} \mathrm{C}\right)$. This model was used to estimate growth rates of planktonic postlarvae and newly settled benthic lobsters. Using the criterion developed by Juinio \& Cobb (1994), the proportion of poorly nourished lobsters was calculated for each year as those with growth rates less than $0.22 \mathrm{mg}$ protein $\mathrm{d}^{-1}$. This criterion was based on the lowest average growth rate of postlarvae reared in the full ration treatments in the laboratory (Juinio \& Cobb 1994). Growth rates of planktonic postlarvae collected in 1991 and 1992 were compared with the 1994 data. The methodology of the
RNA:DNA analyses in 1991 and 1992 was the same as described above. Inter- and intra-annual differences in growth rates of planktonic postlarvae from 1991, 1992 and 1994, and differences in growth rates between recaptured lobsters in 1993 and planktonic and benthic lobsters sampled in 1994, were evaluated using a Kruskal-Wallis test. If a significant difference was found, a least squared means test was performed to determine differences in growth rate among the sampled lobsters. Alpha levels were adjusted accordingly using the Bonferroni Adjusted Alpha (Sokal \& Rohlf 1995). Frequency distributions of growth rates for recaptured lobsters (those originating from laboratory and wild stock) were compared using a KolmogorovSmirnov 2-sample test. Frequency distributions of planktonic postlarval growth rates for 1991, 1992 and 1994 were compared using a Kolmogorov-Smirnov 2 sample test.

\section{RESULTS}

Average surface water temperatures for Bell 4 and the Harbor of Refuge in 1991 and 1992 and surface and bottom temperatures in 1994 are shown in Table 1. Average surface temperatures in 1991, 1992 and 1994 ranged from 18.0 to $19.6^{\circ} \mathrm{C}$ and bottom temperature in 1994 averaged $19.9^{\circ} \mathrm{C}$. Growth rates of planktonic postlarvae in 1994 were compared to those sampled in 1991 and 1992 (Table 2). There were significant differences in growth rates between years (Kruskal-Wallis test: $F=4.29$, df $=2, p=0.0146$ ) (Table 2). In 1994 planktonic postlarvae had significantly higher growth rates than postlarvae in 1991 (Bonferroni Adjusted Alpha, $p<0.0166$; least squared means test, $p=0.0037$ ) but not in $1992(p=0.1498)$. There was no difference in the growth rates between 1991 and $1992(p=0.4921)$. The frequency distributions of planktonic postlarval growth rates were significantly different only for the years 1991 and 1994 (Kolmogorov-Smirnov $\chi^{2}=17.45$,

Table 1 Average water temperature $\left({ }^{\circ} \mathrm{C}, \pm \mathrm{SD}\right)$ at Harbor of Refuge and Bell 4 sampling locations

\begin{tabular}{|ccccc}
\hline Year & Jun & Jul & $\begin{array}{c}\text { Overall } \\
\text { average }\end{array}$ \\
\hline 1991 (surface) & $17.6 \pm 1.2$ & $20.9 \pm 1.3$ & $19.6 \pm 2.0$ \\
1992 (surface) & $16.3 \pm 1.1$ & $18.8 \pm 1.5$ & $18.0 \pm 1.8$ \\
1994 (surface) & $17.5 \pm 1.8$ & $20.9 \pm 1.3$ & $19.2 \pm 2.3$ \\
& Jul & Aug & Sep & $\begin{array}{l}\text { Overall } \\
\text { average }\end{array}$ \\
& & & &
\end{tabular}


Table 2. Homarus americanus. Average yearly and monthly growth rates (mg protein $\mathrm{d}^{-1}, \pm \mathrm{SD}$ ) of planktonic postlarval lobsters for the years 1991, 1992 and 1994

\begin{tabular}{|cccc|}
\hline Year & $\begin{array}{c}\text { Average } \\
\text { growth rate }\end{array}$ & $\begin{array}{c}\text { Jun } \\
\text { growth rate }\end{array}$ & $\begin{array}{c}\text { Jul } \\
\text { growth rate }\end{array}$ \\
\hline 1991 & $\begin{array}{c}0.449 \pm 0.121 \\
(\mathrm{n}=1.66)\end{array}$ & $\begin{array}{c}0.508 \pm 0.107 \\
(\mathrm{n}=63)\end{array}$ & $\begin{array}{c}0.412 \pm 0.114 \\
(\mathrm{n}=103)\end{array}$ \\
1992 & $\begin{array}{c}0.460 \pm 0.144 \\
(\mathrm{n}=40)\end{array}$ & $\begin{array}{c}0.516 \pm 0.116 \\
(\mathrm{n}=22)\end{array}$ & $\begin{array}{c}0.391 \pm 0.147 \\
(\mathrm{n}=18)\end{array}$ \\
1994 & $\begin{array}{c}0.522 \pm 0.247 \\
(\mathrm{n}=78)\end{array}$ & $\begin{array}{c}0.578 \pm 0.201 \\
(\mathrm{n}=16)\end{array}$ & $\begin{array}{c}0.507 \pm 0.257 \\
(\mathrm{n}=62)\end{array}$ \\
& & & \\
\hline
\end{tabular}

$\mathrm{df}=2, \mathrm{p}=0.0368$ ) (Fig. 2a). There were intra-annual differences in the planktonic postlarval growth rates within 2 of the 3 years. In 1991 and 1992, growth rates were significantly lower in July than in June 1991: $F=$ 30.29, df $=1, \mathrm{p}=0.0001 ; 1992: F=7.96, \mathrm{df}=1, \mathrm{p}=$ 0.0075 ) (Table 2); there was no within-season difference in $1994(F=1.51$, df $=1, \mathrm{p}=0.2234)$.
Growth rates of 16 of the recaptured lobsters in 1993 were determined. All of these individuals were recaptured in the sixth instar In 1994, growth rates of 73 early benthic phase lobsters [ 40 wild ( $<10 \mathrm{~mm} \mathrm{CL}$ ) and 33 recaptured individuals] were determined. All recaptured lobsters in 1994 were in the fifth instar. Frequency distributions of growth rates of the 1993 and 1994 recaptures were significantly different (Kolmogorov-Smirnov $\chi^{2}=20.94, \mathrm{df}=2, \mathrm{p}=0.0221$ ) (Fig. 2b). There were also significant differences in the average growth rates between recaptured (1993: $0.085 \pm 0.078 \mathrm{mg}$ protein $\mathrm{d}^{-1} ; 1994: 0.281 \pm 0.176 \mathrm{mg}$ protein $\mathrm{d}^{-1}$ ), wild benthic (1994: $0.223 \pm 0.180 \mathrm{mg}$ protein $\mathrm{d}^{-1}$ ) and planktonic (1994: $0.522 \pm 0.247 \mathrm{mg}$ protein $\mathrm{d}^{-1}$ ) lobsters (Kruskal-Wallis test: $F=37.64, \mathrm{df}=3$, $\mathrm{p}=0.0001$ ) (Fig. 3). Planktonic postlarvae sampled in 1994 had significantly higher growth rates than both recaptured lobsters in 1993 and 1994 and the wild benthic lobsters sampled in 1994 (least squared means test, Bonferroni Adjusted Alpha, $p<0.0083$ : 1993 recaptures, $p=0.0001 ; 1994$ recaptures, $p=0.0001$;
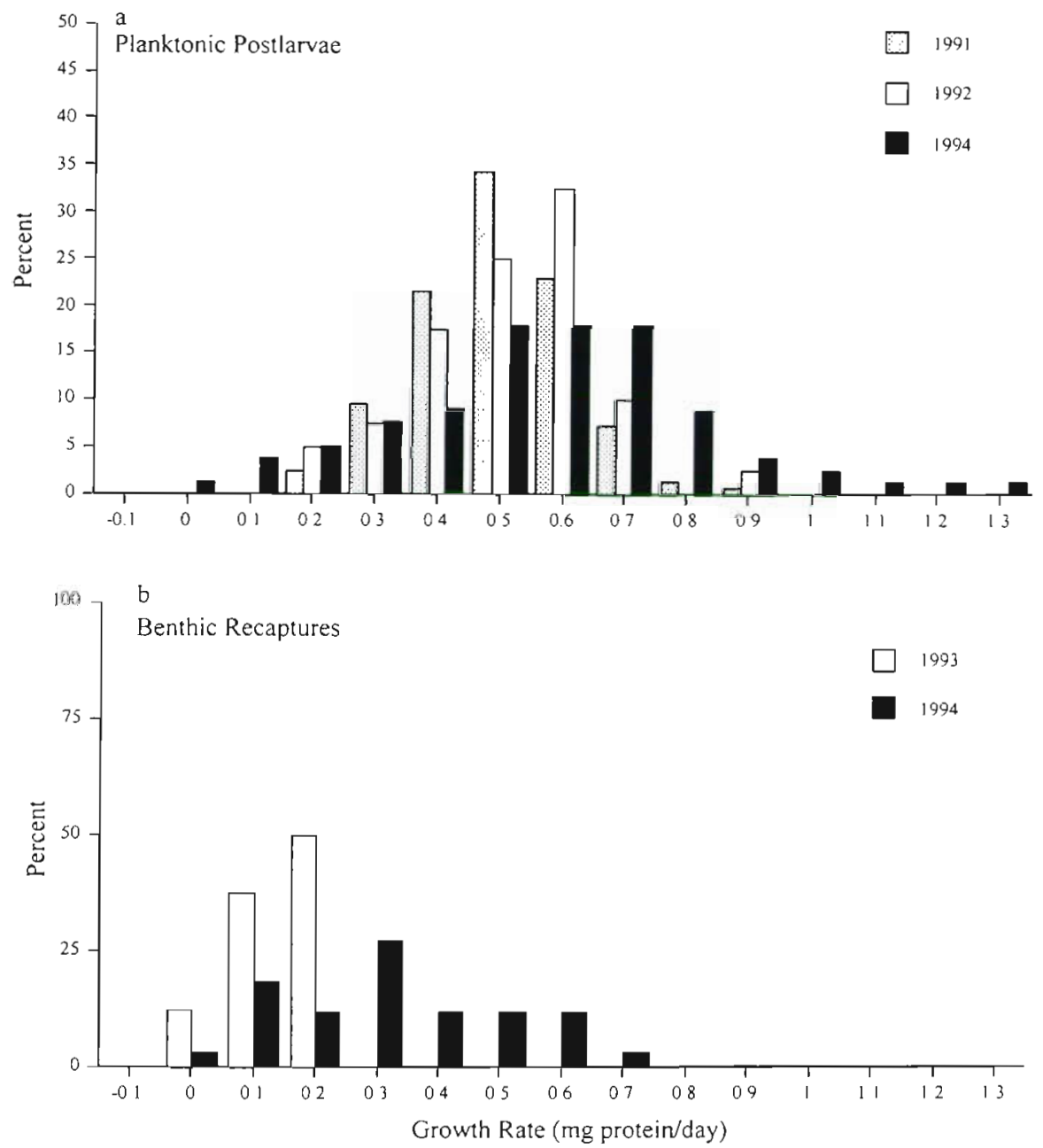

Fig. 2. Homarus americanus. (a) Frequency distributions of planktonic postlarval growth rates for the years 1991, 1992 and 1994. There was a significant difference in frequency distributions between the years 1991 and 1.994 (Kolmogorov-Smirnov 2sample test, $p=0.0368$ ). (b) Frequency distributions of growth rates for recaptured lobsters in 1993 (VI instars) and 1994 (V instars). There was a significant difference in between the frequency distributions (Kolmogorov-Smirnov 2-sample test,

$$
\mathrm{p}=0.0221 \text { ) }
$$




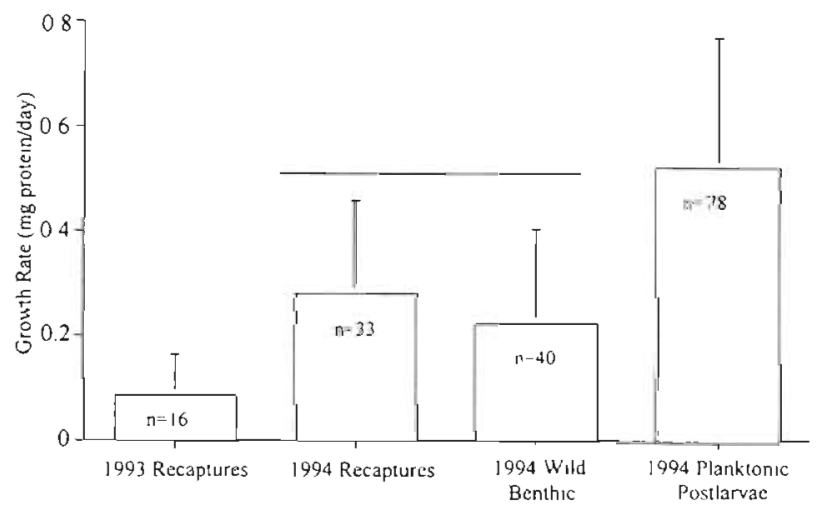

Fig. 3. Homarus americanus. Growth rates + SD and sample size (n) of recaptured and wild benthic juvenile, and planktonic lobsters. Lobsters recaptured in 1993 onginated from laboratory reared stock; those recaptured in 1994 onginated from wild stock. Growth rates of wild benthic juvenule lobsters and planktonic postlarvae are for individuals sampled in 1994. Solid horizontal line indicates groups with statistically similar growth rates

1994 wild benthic, $p=0.0001)$. Laboratory reared recaptured lobsters in 1993 had significantly lower growth rates than both recaptured lobsters and wild benthic lobsters in 1994 (Bonferroni Adjusted Alpha, $p<0.0083: 1994$ recaptures, $p=0.0067$; 1994 benthic, $p=0.0001)$. There was no significant difference in the growth rates of the 1994 recaptured and wild benthic lobsters (Bonferroni Adjusted Alpha, $\mathrm{p}<0.0083$ : $\mathrm{p}=$ $0.1145)$.

Juinio \& Cobb (1994) defined poorly nourshed postlarvae as those with growth rates less than $0.22 \mathrm{mg}$ protein $\mathrm{d}^{-1}$. Using this criterion, the percentage of poorly nourished planktonic postlarvae ranged from $4.2 \%$ in 1991 to $12.8 \%$ in 1994 . The majority of poorly nourished postlarvae in all years were sampled in July (1991: 85\%; 1992: 100\%; 1994: 90\%). In 1994, 65\% of the wild early benthic phase lobsters were poorly nourished. In 1993, all the laboratory reared recaptured

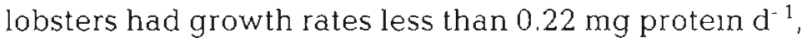
while only $39 \%$ of the wild caught and recaptured lobsters originating from wild stock had growth rates indicative of poor nutritional condition (F1g. 4).

\section{DISCUSSION}

Postlarval lobsters first appear in the plankton in coastal Rhode Island waters in mid June. Postlarvae are usually present in the water column for approxlmately $6 \mathrm{wk}$ and peak abundance usually occurs in late June to early July (James-Pirri 1996, J. S. Cobb unpubl. data). Planktonic postlarval growth rates measured in this study were similar to those observed in previous years in this same region (Juinı \& Cobb

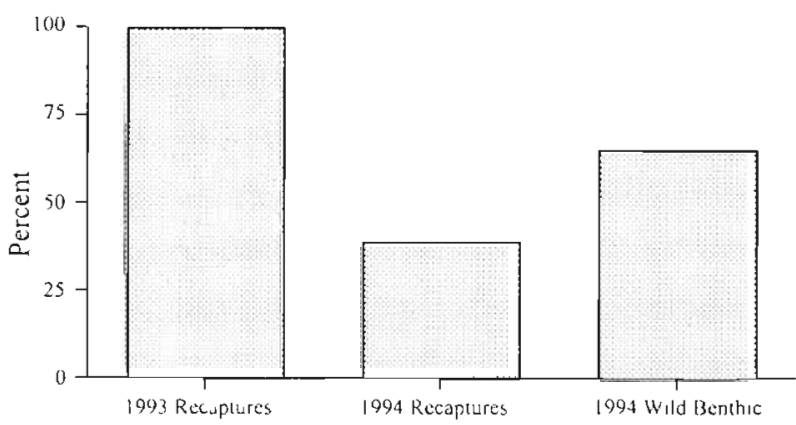

Fig 4 Homarus amenicanus Percent of recaptured and wild benthic juvenile lobsters in poorly nourished condition as judged by the criterion of Juinı \& Cobb (1994), le growth rate less than $022 \mathrm{mg}$ proteln $\mathrm{d}^{-1}$

19941. Growth rates in 1994 were the highest, yet this year also had the highest percentage of poorly nourished postlarvae. The range of growth rates observed in 1994 was the widest, with more individuals in the tails of the distribution than in 1991 or 1992. Since sea surface temperatures were similar among years it is unlikely that temperature caused the observed differences. Although no significant intra-annual difference was observed in 1994, the same trend of higher growth rates in June was apparent. The average dally abundance of planktonıc postlarvae in 1994 was lower than that in both 1991 and 1992 (J. S. Cobb unpubl. data, M. J James-Pirn pers, obs.) and therefore fewer postlarvae were sampled. This resulted in a low sample size for June of 1994 (16 individuals) and may have contributed to the lack of difference in this year The intra-annual differences in growth rates (higher in June than in July) observed in 1991 and 1992 are consistent with previous growth rate estimates for this same area in 1988 to 1990 (Juinio \& Cobb 1994). As in that study, we found that average water temperatures in July were not very different from June in these years. Based on evidence from their field study of planktonic postlarval lobster growth rates and zooplankton biomass estımates, Juınıo \& Cobb (1994) concluded that the lower average growth rates in July could not be attributed to either increasing summer temperatures or food limitation.

The nucleic acid growth model developed for postlarvae (Juinio \& Cobb 1994) was used to assess growth rates of newly settled lobsters $(<10 \mathrm{~mm}$ CL) since no RNA:DNA based model exists for this life history stage. Our rationale for using the existing model was that postmetamorphic instars (IV to V) are bioenergetically sımilar (Capuzzo \& Lancaster 1979, Sasaki et al. 1986). Protein catabolism and lipid reserves are the primary energy source for both the postlarval and fifth instar. Additionally, these instars are blochemically alıke, having similar percent compositions of protein, carbohydrate 
and lipid (Capuzzo \& Lancaster 1979, Sasaki et al. 1986) Newly settled lobsters (V instars) have lower oxygen consumption rates than postlarvae (Capuzzo \& Lancaster 1979], however the relationship between metabolic rate and RNA:DNA ratios is not clearly understood.

Benthic lobsters (wild, 1994 recaptures) had significantly lower growth rates than planktonic postlarvae in 1994. Point Judith Harbor of Refuge is a well-mixed, shallow body of water subject to tidal flushing. Average surface and bottom temperatures in the harbor were very similar (surface $19.2^{\circ} \mathrm{C}$, bottom $19.9^{\circ} \mathrm{C}$ ), thus the lower growth rates of benthic lobsters cannot be explained by temperature differences in this study area. A decrease in either the quantity or quality of ingested benthic prey could also result in lower growth rates of benthic juvenile lobsters. However, a variety of potential prey items [small crustaceans of the genera Cancer (newly settled), Caprella, Gammarus and Jassa and newly settled fish of the genus Tautogolabrus] were abundant in the benthic suction samples from both the wild benthic and recaptured lobster samples (M. J. James-Pirri pers. obs.).

If ample prey were available, the lowered growth rates may be a direct effect of behavior. Newly settled lobsters may have reduced foraging activity, which may be related to a shift in energy allocation or to predator avoidance. Hudon (1987) observed a sharp drop in the growth factor (percent incremental increase in $\mathrm{CL}$ ) at the postlarval-fifth instar transition and suggested the decrease may be a result of more energy being allocated to searching for shelter than to foraging for food. Sasaki et al. (1986) proposed that lipid reserves stored during the postlarval instar (accounting for 3 to $5 \mathrm{~d}$ of metabolic reserves) might be used by the newly settled lobsters during shelter location and construction, allowing adaptation to a new way of life before feeding is a necessity. Recently settled lobsters ( 4 to $14 \mathrm{~mm} \mathrm{CL}$ ) have been defined as the shelter-restricted stage and evidence suggests that they have limited foraging activities (Lawton \& Lavalli 1995). These individuals are highly cryptic and seldom leave the shelter of burrows (Barshaw \& Bryant-Rich 1988) In the laboratory, titth instar lobsters spent significantly more time within the shelter of burrows than newly settled postlarvae (James-Pirri 1996). Newly settled lobsters are capable of surviving on limited foraging activities. While remaining within their shelters, they were capable of surviving and growing on plankton and showed no delay in molting frequency (Barshaw 1989, Lavalli 1991). Lawton \& Lavalli (1995) surmised that, due to ineffectiveness of small claws in catching prey and vulnerability to predators when exposed, the shelter-restricted stage probably feeds by suspension feeding within the shelter and ambushing prey at the shelter entrance.
Young juvenile lobsters have been assumed to trade off growth for increased survival by remaining within protective burrows limiting both foraging activities and risk of predation (Wahle 1992, Wahle \& Steneck 1992). Newly settled lobsters are vulnerable to predation by benthic fishes and crabs (Lawton and Lavalli 1995). Predation has been hypothesized as the major mechanism enforcing the strict association of the newly settled lobsters with shelters (Wahle \& Steneck 1992, Cobb \& Wahle 1994). Potential epibenthic and benthic predators abundant in the study area included cunner (genus Tautogolabrus), sculpins (genus Myoxocephalus), juvenile Homarus americanus (5 to $50 \mathrm{~mm}$ $\mathrm{CL}$ ), crabs (genus Cancer) [4 to $50 \mathrm{~mm}$ carapace width (CW)], Hermit crabs (genus Pagurus) and spider crabs (genus Libinia). A Cancer crab tethering experiment conducted at the same time as this study in another area of the Harbor of Refuge indicated high predation mortality (50 to $60 \%$ ) of tethered crabs ( 5 to 20 and 25 to $40 \mathrm{~mm} \mathrm{CW}$ (Clancy 1995). Additionally, a caged treatment $(2.5 \times 1.25 \mathrm{~cm}$ mesh $)$ did not significantly alter mortality rates, indicating the presence of predators small enough to enter the cages (Clancy 1995). The lowered growth rates observed in this study are supportive of the restricted foraging activity of newly settled lobsters. It cannot be determined if predator avoidance or a shift in energy allocation (from foraging to shelter acquisition) contributed more to this reduction in growth rates.

The laboratory reared lobsters used in the recapture experiments in 1993 had lower growth rates than the 1994 recaptures that originated from wild stock. Benthic lobsters were sampled in 2 different years and were different instars (1993: VI instar; 1994: $\mathrm{V}$ instar) and it is possible that the observed growth rates were the result of either inter-annual or instar differences. However, we believe it is possible that the postlarval source (wild vs laboratory reared) was responsible for the observed differences in growth rates. Laboratory reared larval lobsters, in general, differed dramatically from their wild counterparts. Laboratory postlarvae were typically smaller, had weaker exoskeletons, were lighter in color and had reduced growth rates compared to wild postlarvae (Lavalli 1991, Juinio \& Cobb 1994, M. J. James-Pirri pers. obs.). Since nucleic acid analysis of postlarval and juvenile lobsters requires that the individual be sacrificed, it is not possible to know the growth rates of the laboratory reared lobsters before they were transplanted into the field. However, we can attempt to estimate their growth rates based on feeding regime and previous laboratory studies. Under good conditions in the laboratory, postlarvae reared on the same diet (frozen adult brine shrimp ad libitum) can add protein at a rate of $0.26 \mathrm{mg}$ protein $\mathrm{d}^{-1}$ (Juinio $\&$ Cobb 1994, Ennis 1995). We, therefore, can estimate 
the growth rates of the tagged laboratory reared lobsters prior to transplantation to the field at approximately $0.26 \mathrm{mg}$ protein $\mathrm{d}^{-1}$ The growth rates of the laboratory reared recaptured lobsters were much lower than this, averaging only $0.085 \mathrm{mg}$ protein $\mathrm{d}^{-1}$ If our estimate is correct, it suggests that the growth rates of the laboratory reared lobsters decreased while they were in the field. In contrast, the average growth rate of the recaptured lobsters originating from wild stock was $0.281 \mathrm{mg}$ protein $\mathrm{d}^{-1}$, suggesting that these lobsters' growth rates increased while they were in the field (if we assume the same $0.26 \mathrm{mg}$ protein $\mathrm{d}^{-1}$ estimate at transplantation). The cause of the low growth rates of the laboratory reared recaptured lobsters is unknown, but may be due to an inability of these lobsters to either recognize or capture prey in the wild.

Similar trends in RNA and DNA ratios have been observed in pueruli and juvenile Western rock lobster Panulirus cygnus (Lemmens 1995). In this species the puerulus is the transitory stage between the planktonic and benthic habitats (Phillips \& Sastry 1980, Herrnkind et al. 1994). However, unlike the postlarval instar of the American lobster, the puerulus stage is a non-feeding stage; energy reserves accumulated in the phyllosoma (larval stage preceding the puerulus) are utilized in the puerulus stage (Lemmens 1994). The first juvenile stage after the puerulus is the first feeding stage (Phillips \& Sastry 1980, Herrnkind et al. 1994). If foraging is not associated with mortality, one would expect the first feeding juvenile stage to have higher growth rates than the non-feeding puerulus stage. However, Lemmens (1995) observed both the puerulus and juvenile stages to have lower RNA:DNA ratios than the phyllosomata. The lowered growth rates in the first feeding juvenile stage is suggestive of a trade-off between foraging and growth in this species as well.

Estimates of in situ growth rates during the settlement period in other species have also been reported. In stone flounder Kareius bicoloratus, growth rates were higher for post-settlement juveniles collected in April than for newly settled juveniles in March (Malloy et al. 1996). These authors suggested the higher growth rates could have been due to the larger juveniles being able to forage on a wider spectrum of prey (Malloy et al. 1996). Alternatively, lowered growth rates of the newly settled flounders could be a result of a trade-off between foraging and mortality in this smaller stage. Lowered growth rates may be caused by predator avoidance, as newly settled flounders may spend more time buried in the substrate than larger juvenile stages.

Lobsters that remain within their burrows may experience a decrease in growth, however the reduced risk of mortality may greatly outweigh the consequences of reduced growth rates in the short term. Vulnerability of early benthic phase lobsters to predation has been observed to decline with small incremental increases in body size (Wahle \& Steneck 1992). There may be a threshold body size at which, once reached, the risk of predation is greatly reduced. Once this threshold body size is reached, active foraging may begin and growth rates would increase. Indeed, increases in the growth factor have been observed in later juvenile stages (VI instar and older) (Hudon 1987, James-Pirri 1996). Therefore, as long as some grow occurs and body size increases, the consequences of slower growth outweigh the risk of active foraging and exposure to predation.

We hypothesized that if newly settled lobsters trade off foraging for decreased risk of predation, growth rates should be lower for juvenile lobsters than for postlarvae. We found evidence to support this hypothesis; newly settled wild juvenile and recaptured lobsters had significantly lower growth rates than planktonic postlarvae. Growth rates may be one of several factors influencing survival during the settlement period of the life history of the American lobster. Future studies should concentrate on the transitional period between the planktonic and the benthic habitat to further elucidate the factors influencing cohort success in this species.

Acknowledgements. This research was part of the PhD dissertation submitted to the University of Rhode Island by M.J.J.-P. We are grateful to many graduates and undergraduates who assisted in the field and in the laboratory. We thank Rick Wahle, Kari Lavalli, Alexis Clark Rundstadler, New England Aquarium and Northeastern University for supplying laboratory reared larval lobsters. Marian Goldsmith, Jennifer Specker and Saran Twombly kindly offered the use of laboratory equipment. The manuscript was improved by 3 anonymous referees who critically reviewed the manuscript. This research was supported by 2 Grants-in-Aid of Research from Sigma Xi, The Scientific Research Society (M.J.J.-P.), LernerGray Grant for Marine Research (M.J.J.-P.), and a University of Rhode Island Graduate Student Fellowship (M.J.J.-P.). Funding to J.S.C. from the Rhode Island Sea Grant Program and the Cooperative Marine Education and Research Program (URI-NMFS) provided M.J.J.-P. with supplies and summer research stipends.

\section{LITERATURE CITED}

Barshaw DE (1989) Growth and survival of early juvenile American lobsters, Homarus americanus, on a diet of plankton. Fish Bull US 87:366-370

Barshaw DE, Bryant-Rich DR (1988) A long-term study on the behavior and survival of early juvenile American lobster, Homarus americanus, in three naturalistic substrates: eelgrass, mud, and rocks. Fish Bull US 86:789-796

Buckley LJ (1979) Relationships between RNA-DNA ratio, prey density, and growth rate in Atlantic cod (Gadus morhua) larvae. J Fish Res Bd Can 36:1497-1502

Bulow FJ (1987) RNA-DNA ratios as indicators of growth in fish: a review. In: Summerfelt RC, Hall GE (eds) The age 
and growth of fish. Iowa State University Press. Ames, p 45-65

Capuzzo JM, Lancaster BA (1979) Some physiological and biochemical considerations of larval developmental in the American lobster, Homarus americanus Milne Edwards. J Exp Mar Biol Ecol 40:53-62

Charmantier G. Charmantier-Daures M. Aiken DE (1991) Metamorphosis in the lobster Homarus (Decapoda): a review. J Crustac Biol 11:481-495

Clancy M (1995) Recruitment of the rock crab, Cancer irroratus: the influence of larval supply, settlement and post-settlement processes to benthic distribution patterns. PhD dissertation, University of Rhode Island, Kingston

Cobb JS, Wahle RA (1994) Early life history and recruitment processes of clawed lobsters. Crustaceana 67:1-25

Ennis GP (1995) Larval and postlarval ecology. In: Factor JR (ed) The biology of the lobster, Homarus americanus. Academic Press, New York, p 23-46

Herrnkind WF, Jernakoff P, Butler MJ (1994) Puerulus and post-puerulus ecology. In: Phillips BF, Cobb JS, Kittaka J (eds) Spiny lobster management. Blackwell Scientific. Cambridge, MA, p 213-229

Hudon C (1987) Ecology and growth of postlarval and juvenile lobster, Homarus americanus, off lles de la Madeleine (Quebec). Can J Fish Aquat Sci 44:1855-1869

James-Pirri MJ (1996) Growth and behavior during the settlement period of the American lobster, Homarus americanus. PhD dissertation, University of Rhode Island, Kingston

Juinio MAR (1991) Feeding ecology of the postlarval lobster Homarus americanus. PhD dissertation., University of Rhode Island, Kingston

Juinio MAR, Cobb JS (1994) Estimation of recent growth of field-caught postlarval American lobsters, Homarus americanus, from RNA:DNA ratios. Can J Fish Aquat Sci 51: 286-294

Juinio MAR, Cobb JS, Bengtson D, Johnson M (1992) Changes in nucleic acids over the molt cycle in relation to food availability and temperature in Homarus americanus postlarvae. Mar Biol 114:1-10

Langton RA, Steneck RS, Gotceitas V, Juanes F, Lawton P (1996) The interface between fisheries research and habitat management. N Am J Fish Manage 16:1-7

Editorial responsibility: Gareth Harding (Contributing Editor), Dartmouth, Nova Scotia, Canada
Lavalli KL (1991) Survival and growth of early juvenile American lobsters Homarus americanus through their first season while fed diets of mesoplankton, microplankton and frozen brine shrimp. Fish Bull US 89:61-68

Lawton P, Lavalli KL (1995) Postlarval, juvenile, adolescent, and adult ecology. In: Factor JR (ed) The biology of the lobster, Homarus americanus. Academic Press, New York, p $47-88$

Lemmens JWTJ (1994) Biochemical evidence for absence of feeding in the puerulus larvae of the Western rock lobster Panulirus cygnus (Decapoda: Palinuridae). Mar Biol 118: $383-391$

Lemmens JWTJ (1995) Nucleic acid levels, cellular activity and growth during the puerulus stage of the Western rock lobster (Panulirus cygnus (George); Decapoda: Palinuridae). J Exp Mar Biol Ecol 194:143-156

Malloy KD, Yamashita Y, Yamada H, Targett TE (1996) Spatial and temporal patterns of juvenile stone flounder Kareius bicoloratus growth rates during and after settlement. Mar Ecol Prog Ser 131:49-59

Phillips BF. Sastry AN (1980) Larval ecology. In: Cobb JS, Phillips BF (eds) Biology and management of lobsters, Vol 1. Academic Press, New York, p 11-57

Sasaki GC (1984) Biochemical changes associated with embryonic and larval development in the American lobster Homarus americanus Milne Edwards. PhD dissertation, Massachusetts Institute of Technology/Woods Hole Oceanographic Institute, Woods Hole

Sasaki GC. McDowell Capuzzo J, Biesiot P (1986) Nutritional and bioenergetic considerations in the development of the American lobster Homarus americanus. Can J Fish Aquat Sci 43:2311-2319

Sokal RR, Rohlf FJ (1995) Biometry. WH Freeman, New York

Wahle RA (1992) Substratum constraints on body size and the behavioral scope of shelter use in the American lobster. J Exp Mar Biol Ecol 159:59-75

Wahle RA, Steneck RS (1991) Recruitment habitats and nursery grounds of the American lobster Homarus americanus: a demographic bottleneck? Mar Ecol Prog Ser 69:231-243

Wahle RA. Steneck RS (1992) Habitat restrictions in early benthic life: experiments on habitat selection and in situ predation with the American lobster. $J$ Exp Mar Biol Ecol 157:91-114

Submitted: January 14, 1997; Accepted: October 28, 1997 Proofs received from author(s): November 28, 1997 